\title{
Belief in the Spirits of the Dead in Africa: A Philosophical Interpretation
}

\author{
Crispinous Iteyo \\ Department of Philosophy and Religious Studies \\ Maseno University \\ citeyo@yahoo.com \\ Thought and Practice: A Journal of the Philosophical Association of Kenya (PAK) \\ Premier Issue, New Series, Vol.1 No.1, June 2009, pp.147-159 \\ thoughtandpractice@uonbi.ac.ke OR thoughtandpractice@gmail.com
}

\begin{abstract}
This paper offers a philosophical interpretation of belief in the spirits of the dead in Africa, with a view to identifying rational grounds for accepting or rejecting them. This endeavour is premised on the view that in this rapidly changing world, philosophy should inquire not only in to theoretical problems, but also into practical ones. Plato and Aristotle's theories of the soul being some of the most carefully discussed philosophical theories on immortality or lack of it, will provide the background of deliberation in this paper.
\end{abstract}

\section{Introduction}

In the world today, science and technology seem to permeate every aspect of human life. In-vitro fertilization, surrogate motherhood, genetic engineering, life support devices and genetically modified foods are among the myriad recent innovations. They attend to the material needs of human beings, thereby perhaps putting to doubt the value of generally theoretical disciplines such as philosophy. Nevertheless, the meeting of material needs does not necessarily satiate the range of human yearnings, because there are many issues of intense metaphysical and moral concern to humans that material things per se cannot address. Thus in spite of the scientific and technological advances, there is need to ask philosophical questions about challenges 
such as fanaticism, discrimination, governance, the environment, cultural practices, and human destiny.

In Africa, according to Mbiti (1969, 149), “there are many, and often complicated ceremonies connected with death, burials, funerals, inheritance, and the living dead, among others", because belief in the spirits of the dead is common and widespread.

This paper offers a philosophical interpretation of belief in the spirits of the dead in Africa, with a view to identifying rational grounds for accepting or rejecting them. This endeavour is premised on the view that in this rapidly changing world, philosophy should inquire not only in to theoretical problems, but also into practical ones. The paper is divided in to two sections. In the first, the term culture is explained and belief in the spirits of the dead among the Luba, Akan, Mende, Banyaranda and the Luo described, with special focus on Luo beliefs. The Luo are an ethnic group found around Lake Victoria in western Kenya, as well as in parts of Uganda and Tanzania. They belong to the larger linguistic stock called the Nilotes. In the second segment, philosophical interpretation and analysis of Luo beliefs about death is made. Plato and Aristotle's theories of the soul, by far the most carefully worked out philosophical theories on immortality or lack of it, provide the background for the discussion.

\section{Conceptualising Culture}

Beliefs are key components of culture, largely influencing human behaviour. They are handed over from one generation to the other, sometimes with modifications. Culture influences people ostensibly because it provides them with anidentity and a worldview through which they understand or interpret the cosmos. It is prudent therefore at this juncture to have a bird's eye view of culture. 
In the 1870's according to A.T. Dalfovo in his article, "Culture: Meaning and Relation to Philosophy", there was a shift in the understanding of culture from the personal to the social. For him, the new understanding emanated from Edward Taylor's definition of culture in 1871 as the complex whole that includes among other things knowledge, beliefs, art, morals, law, and custom. This view gradually entrenched itself, so that it is now the prevailing understanding of culture.

The social understanding of culture marked a shift from the theoretical to the empirical meaning, as a result of which humans were rescued from the notion of being cultured to the one of belonging to a culture. They were now seen as belonging to but not being, with the implication that no one would be without culture. This was in sharp contrast to the earlier theoretical interpretation, where some people would be cultured but others not. According to that earlier view, as something that could be possessed, culture meant the development, improvement and refinement of persons through education and training. This was in conformity with the meaning of the Latin word cultura (cultivation; attending to the land for the raising of crops). Applied to humans, the usage of culture tended to focus on the person, implying first of all an awareness of certain ideas, being conversant with certain mannerisms, possessing certain traits, and behaving accordingly. Thus according to the earlier theoretical perspective, culture was conceived normatively, stressing values rather than facts. Consequently, enculturation implied the cultivation of ideas, principles and traits that would have automatically resulted in "proper" behavior. A cultured person was hence a knowledgeable person, whose learning was followed by appropriate conduct. On the other hand, an uncultured person was not learned, and hence not refined in manners.

The shift from the person to society and from the theoretical to the empirical, meant that the emphasis moved from knowledge to behavior, that is, from theory to practice. A synthesis of the components of culture as empirical is summarized in a simple phrase - "a way of life". Hence to Oruka (Oruka\& Masolo, 1983, p57), culture is a people's body of knowledge, beliefs, behavior, goals, social institutions, together with tools, techniques and material constructions. It is in this light that one can talk of European culture, African culture, or Chinese culture. In this sense one can say it is one's culture to do or not to do certain things, for example, initiating boys into 
adulthood by circumcising them. It is in this sense that belief in the spirits of the dead is examined herein.

The "way of life" is not static, but is rather susceptible to influences from other "ways of life". Internal or external forces can bring gradual or massive change. On this note we can ask what exactly African culture is. This would be asking about the identity of the African way of life, whether it is traditional or modern. This is because there are elements of modernity and traditionalism in the contemporary African "way of life". This phenomenon has a historical explanation in colonization. As Thairu (1975) laments, colonialists introduced their culture that included religion, language, clothing, food, music, health care and a set of beliefs that Africans were conditioned to adopt. Okot p'Bitek captures this vividly when he states:

... contrary to the African idea that everybody must marry in the prime of their youth, have a family (and for a man, the more wives and children he has the better), young intelligent, beautiful and handsome Africans were lured to think that wifelessness, husbandlesness, childlessness, homelessness, were a virtue. (1986, p15).

During the colonial era, terms such as "cultured" and "uncultured" - indicative of the theoretical and personal meaning of culture - were in vogue, perhaps as a technique of luring Africans to abandon their culture. A cultured African was that one who shed his traditional culture and embraced the Western one, while an uncultured African was that one who stuck to his/her traditional way of life. The 'uncultured African' was seen as "backward".

As much as colonialism disrupted African traditional culture and introduced what may be called modernity, the divide in terms of who or what is traditional and who or what is modern is not succinct, because 'traditional culture' was not obliterated. Some aspects of European culture have become part of culture in Africa, having been fully embraced. In other instances, both traditional and modern remedies may be sought to solve problems. Placide Tempels captured this fact thus:

... among our Bantu we see the evolues, the 'civilized', even the Christians, return to their former ways of behavior whenever they are overtaken by moral lassitude, danger or suffering. They do so because their ancestors left them their practical solution of the great problem of humanity, the problem of life and death, of salvation or destruction (Tempels 1959, 18). 


\section{Spirits of the Dead in African Cultures}

Belief in the spirits of the dead in African cultures is widespread, as evidenced in the examples of the five African communities below.

In the Luba thought as Tempels (1959) writes, there is belief that the dead fathers of the community still exist but in spirit form. After God in terms of force, he writes, come the first fathers, founders of the different clans. The ancestors constitute the most important chain, binding humans to God. They occupy an exalted rank, in that they are not regarded as the ordinary dead. They are, in Tempels' view, spiritualized beings, being higher on the ontological hierarchy, participating to a certain degree in the divine force. After the first fathers were the dead of the tribe, following their order of primogeniture. They according to Tempels formed a chain through which the forces of the elders exercised their vitalizing influence on the living generations.

The Akan people, according to Gyekye (1987) similarly have a conception of the spirits of the dead, manifested in their religious language, attitude, and practices. For example, the language of the religious rite of libation runs as follows:

Supreme God, who is alone great, upon whom Men lean and do not fail, receive this wine and drink. Earth goddess, whose day of worship is Thursday, receive this wine and drink. Spirits of our ancestors receive this wine and drink (Gyekye, 1987, 85)

Writing on the Mende, Little (1976) observes that the ontology is that of spirits. At the apex of the hierarchy there is Ngewo, the super spirit - Supreme Being. Below the Supreme Being are spiritual beings that fall broadly into two categories, ancestral, and non-ancestral spirits. The ancestral spirits are the spirits of former living members of the community - both former members of the various cults, as well as individual families. The non-ancestral spirits comprise certain widely known spirits or genii (Dyinyinga), associated quite often with natural phenomena such as rivers, forests and rocks, but not confined to any one locality.

In presenting the cosmology of the Rwandese, Maquet (1976) says that the Banyarwanda view reality in two perspectives - from that of the material and that of the non-material world. The non-material world is composed of two categories, namely, that of God - Imana, and (2) the spirit of the dead Bazimu. The Bazimu 
continue the individuality of living persons, and have the same names. Though nonmaterial, they are localized by their activity. They are viewed as not drinking, eating, or mating, but their existence in other respects is similar to that in the world of the living. The Bazimu sometimes come back to the world, returning to the places where they used to live. These spirits may stay permanently in the hut where their descendants live, or in the small huts made for them in the enclosure around the homes. Whatever their temperament was when they were in this world, it is believed, the Bazimu are bad. In order not to irritate them, various observances and interdictions must be complied with. Hence, there is the 'cult' of the Bazimu, which among other things, aims at appeasing the spirits.

In Luo culture, belief in the spirits of the dead provides a basis for most of the practices that take place from the time one dies to the end of the mourning period. According to Oruka, spirits of the dead are to be feared since, if one does not comply with the customs, then he/she is haunted by them. Asked in a court proceeding why a burial ceremony has to be performed at even a drowned person's home, he answered that if the ceremonies were not done, "the spirits of the dead would haunt the people, claiming they were ignored" (Oruka 1991, 71). The belief is that a human being is made up of visible (the body) and invisible parts (tipo). The union of the two parts forms human life. At death the body perishes, but tipo becomes the spirit. The spirit retains the individual identity, but becomes more intelligent and powerful than in the previous life. The spirit becomes jachien (demon) if and when the circumstances surrounding ones death were either not honorable or questionable (for example if it was through suicide). Spirits, in their spiritual form though, according to OchollaAyayo, (1989), are not separated from their clan.

The above Luo beliefs lead to certain practices during and after the mourning period. For example, the dead have to be accorded due respect with the consequence that, among other things, dead bodies must be disposed of in a dignified and respectful manner, with all ceremonies that befit it; no farming and other economic activities are to take place in the vicinity of the bereaved home, because the dead is mourned by the community, and not simply by the family; funeral attendants must be fed; bodies must be buried in coffins and in their homes and if possible, graves should be plastered; funeral fire, magenga, must be lit and be on for seven days after the burial of a man, 
and for three days for a woman; several ceremonies after burial, for example, nindo $e$ liel, tero buru, and tero tipo take place in order to appease the spirits.

Although the procedure observed and the amount of money spent in burials in the Luo culture may show variations according to sex, age and social status as well as certain peculiarities, Ayiemba (1986) observes that if the dead was not a celebrity, a certain minimum number of animals is required for slaughter. If the dead man was married and had grown up children, for example, there has to be a bull for the elders, a bull for sons-in-law, a bull or goat for wife or wives' relatives, and a he-goat for maternal relatives. If his social, political or economic status was high, more animals would be needed.

\section{Interpretation and Analysis.}

In all the cultures mentioned above, there is the conception of the world of spirits. The categories of spiritual beings in this world differ from one thought system to the other. Nevertheless, it is apparent that there is the category of God or the Supreme Being, and then the category of "other spirits", that is, ancestral spirits and/or "the spirits of the dead". Spirits are believed to have more power than humans, but have less power than God. Some may be seen as having places of abode, while others seem to wander in the wilderness. Because they have more power than humans, they are capable of diminishing or increasing human power. To avoid the diminishing and to enhance the increment of power, humans placate them through prayer or other practices such as naming the newborn after departed relatives, or burying the dead with pomp and funfair. In short, spiritual entities are taken to be so real as not to be left out of a people's ontological conception. This implies belief in life after death. When one dies, he or she becomes a spirit, and moves into the world of spirits where spiritual powers are acquired, and thereby able to positively or negatively affect the living. This is what calls for a philosophical analysis.

Death and the common views and beliefs that surround it pose philosophical problems, for example, whether or not there is life after death and if so, what its nature is. These questions can best be discussed against the background of Plato and 
Aristotle's philosophical theories on the soul, not on the assumption that they are true, but as a framework for a systematic analysis of the phenomenon.

Before Plato's theory, Pythagoras, a mystical thinker, had taught that man, who was intermediate between God and the brutes, had a soul which after death migrated into other bodies. Compared with the gods, he held, man is very low and subject to error and death, but compared with the animals he is high up, capable of rising to greater heights. However, man could only rise to greater heights by purifying the soul. Pythagoras formed the orphic brotherhood to 'save souls' by teaching its membership steps to purify their souls.

Plato's theory of the soul is found in Phaedo, where he holds "that the soul is not only immortal, but also that it contemplates truths after its separation from the body at the time of death". This assertion has two implications, namely, (1) that the soul does not perish at the time one dies, and (2) that the soul is characterized by cognitive features. This is explained by a number of reasons. First, the soul is immortal because it is exempted from dissolution and destruction, being among things that are not perceptible, but rather intelligible. Second, the soul is immortal because it is cyclical, in the sense that being alive is preceded by being dead, with the implication that ones 'death involves the continued existence of the soul in question', which goes on to animate another body. Third, 'the soul is immortal because it has life essentially', which implies that at no time can it cease to have life.

In view of the foregoing, it can be inferred that for Plato, the human being is an amalgam of perishable body and immortal soul, meaning that there can be life after death. Death only separates the soul from the body. As the body perishes, the soul continues with life. Regarding the nature of the soul's existence after ones death, Plato held that the soul of a person who was pure, one liberated from the things of the body, departs to the invisible world, to live in bliss in the company of the gods, but that of an impure man, the one who loved things of the body, becomes a ghost or enters into the body of an animal, for example a wolf or a hawk.

Aristotle's theory of the soul is embodied in his account of form and matter, which holds that every material being is composed of prime matter and substantial form as 
its ultimate constituent principles. Substantial form is constant and unchanging, but prime matter comes and goes with every successive change to which the body is subjected. Matter is anything which has extension, that is, it occupies space. In living things, the substantial form is the soul, which is the source of the body's functions and behavior. Plant soul he called "vegetative soul", animal soul "sensitive soul", and that of man he called "rational soul". This is in a way equating life with soul, for to Aristotle, they both meant breath, which he saw as that which greatly differentiates living from non- living things. In summary, for Aristotle, 'soul is a particular kind of nature, a principle that accounts for change and rest' in living things. For Aristotle, living things function in their specific manner by virtue or potency of their souls. Thus Aristotle agree with Plato that the soul and not the body is the animating principle of a living thing. He however differed with Plato regarding the destiny of the soul. The implication of Aristotle's theory is that a person's soul has no life after his death. Death would ipso facto mean that the soul has ceased to be.

These two theories have relevance to the belief in the spirits of the dead in a number of ways. First, there is the categorization of things in to form and matter. The categorization does not only provide for incorporeal substances such as the soul, but also opens up the possibility of an afterlife because if the soul is imperishable, then it outlives the body. But the provision and possibility is wrought with problems, for example the need for a justification of the belief that the soul is, and that it survives bodily death. Although Plato and Aristotle attempt to address these problems in their theories, the questions still remain. For example, to Plato the soul is a simple and immaterial entity containing no parts, and that which activates the body. It is the principle of motion as it is intrinsically active. Aristotle concurred with this by stating that it is the soul that differentiates living from non-living things - that the soul is the life of the body without which the body loses life and therefore activity because the soul is essentially life. However, these postulations do not prove that souls exist. The soul is only seen as the explanation of the activity in living things, and this is simply speculation.

With the two conceptions above having failed to establish that souls exist, another approach is needed, perhaps the rationalistic one. From the rationalistic viewpoint one has to start like Plato and Aristotle with the premise that the soul is that which makes 
a thing active, and that two kinds of things are observed in nature, namely, living and non-living ones. What living things have and non-living things lack is activity or life. When this activity or life vanishes, the body becomes a non-living thing. One then can move on to argue that if the thing that gives activity or life to the body is what is called the soul, then "soul" exists. This is simply arguing thus: living things are differentiated from non-living things because they contain activity; living things contain one thing that non-living things lack; if "the thing" in living things is what is called 'soul' then the soul exists; meaning that the soul must be the explanation of activity in living things.

Nevertheless, the rationalistic approach assumes that things were created the way they are and hence living and non-living things will remain so. However, if taken in the context of evolution, one may argue that living things are not special, but are only a step ahead in this natural process, so that 'non-living' things today may be 'living' tomorrow. What this means is that "living" is simply a capacity rather than a substance (soul) that can depart from the body at death. Hence there is no entity called "soul", but merely the capacity or activity associated with a living body - perhaps agreeing with Aristotle.

If it is granted that there are souls, the question of their destiny arises. An answer to the question of what happens to the soul when one dies is derivable from the conceptions of the relationship between the body and the soul. There are notably two different conceptions regarding the relationship of these two. The first one is that which is advocated by Aristotle, that the soul as the form of the body is bound up with the body, its work being to move the body and perceive sensible objects. It makes the body an organic whole, having purpose as a unit. To this conception, it is not possible to separate the two, as they are related as matter and form. A view resulting from this is that the soul ceases to be at death, being incapable of having further existence beyond bodily death. The implication of this is that the soul is mortal.

The second conception is that which supposes that the soul can depart from the body. This conception considers a living thing as composed of two primary principles body and soul. The main proponents of this view as already observed were Pythagoras and Plato. Pythagoras and his orphic brotherhood taught the transmigration of the 
soul. After a person's death, they believed, the soul picked up another body, transforming into other kinds of living things. This means that whatever comes into existence is thereby born again in the cycles of life, nothing being absolutely new. Therefore just as a person casts off worn-off garments and puts on others that are new, the embodied soul casts off dying bodies and takes on others that are new. And to Plato's theory, the soul is some kind of a "prisoner" trapped in a body, and that the purpose of philosophy is to free the soul from its entrapment in the body, that is, to enable it to attain its highest perfection (Lisska 1977, 102). This conception, therefore, leads to the view that the soul can be separated from the body. To George Galloway, some cultures highly subscribed to this view and even held that the soul "could detach itself from the body to roam at large in the world, and hence one would wake up where he lay down but in the interval his/her soul would have been abroad on strange adventures" (1960, p93). This conception lays ground for the separation of the soul from the body at death, and also the belief in the immortality of the soul, and the possibility of it existing as a spirit as its destiny would most probably be destined to the ontological mode of spirits.

On the empirical front, there are reports that not only suggest that there are "souls", but also that there is life after death. For example, people who had been declared dead but who had been resuscitated, have reported their experiences (Hick 1993, 129). The implication of this is that if there are souls, they are capable of independent existence from the body. Further, in Hindu and Buddhist cultures, it seems self-evident that people have lived many times before and must live many times again in this world (Hick 1993, 133). Evidence for this is that some people claim to have certain memories of people and events experienced in a previous life, and that some impartial investigators end up confirming such occurrences. Such claims may reinforce the view that indeed there are souls.

However, one major weakness of the reports from those resuscitated and re-incarnated is that they present two different claims about the same thing. Is it not contradictory that the same thing (soul) should be re-incarnating in one culture and in the other moving straight to the "world of spirits"? Differently put, does one's soul transmigrate because one is born in say Hindu culture, and that the other goes to heaven/hell because one is born say in a Christian culture? One may come to the 
conclusion that either only one of these is true, or that both are false. The possibility of both of them being false would inevitably mean that there are no souls or that if they are there, they perish with the body, and this might imply that there are no spirits of the dead.

Obviously, believers in the spirits of the dead would subscribe to the second conception of the destiny of the soul, which is that the soul is preordained to proceed to the ontological mode of spirits - that it disembarks from a dying body and moves on. However, it can be argued that even if the second conception is true, that there are souls that transmigrate or become spirits or go to heaven or hell at the death of a person, there would still be need for a strong argument in support of the view that the soul or the spirit still gets interested in the dead body to the extent that the manner in which the dead body is disposed, where it is disposed, how long it takes to be disposed, and how the mourners are treated, may irritate or please it. One may be perfectly correct to assert that if souls exist and become spirits at one's death they may not be bothered with how the body is treated, because the relationship between soul and body will have come to an end.

\section{References}

Ayiemba, E.O. 1986. "Sagacity" in Were,G.S., B.E. Kipkorir, and E.O. Ayiemba Eds. South Nyanza District Socio-Cultural profile. Nairobi: Institute of African Studies, University of Nairobi, pp.17-27.

Bostock, D. 1986. Plato's Phaedo. Oxford: Clarendon Press.

Byrne, E.F. 1969. Human Beings and Being Human. New York: Meredith Corporation.

Dalfovo, A.T. "Culture: Meaning and Relation to Philosophy". Nyasani, J.M. ed. Philosophical focus on Culture and Traditional Thought Systems in Development. Nairobi: Evans Brothers (Kenya) Limited.

Ferguson, J. 1970. Socrates: A Source Book. London: Macmillan and Co. Ltd. Galloway, G. 1960. The Philosophy of Religion. Edinburgh: T \& T. Clark.

Gyekye, K., 1987, An Essay on African Philosophical Thought: The Akan conceptual scheme. Cambridge: Cambridge University Press.

Hick, J. 1993. Philosophy of Religion, $4^{\text {th }}$ Ed. New Delhi: Prentice Hall of India, Ltd. Jowett, Benjamin Trans. 1953. The Dialogues of Plato. Oxford: Clarendon Press.

Lisska, J.A. 1977. Philosophy Matters. Columbia: Charles E. Merril Publishing Company. 
Little, K., 1976. "The Mende in Sierra Leone". Forde, Daryll ed. African Worlds: Studies in the Cosmological Ideas and Social Values of African Peoples. Oxford: Oxford University Press.

Longman Concise English Dictionary, 1985, Longman Group U.K. Limited Burnt Mill, Harlow.

Maquet, J.J., 1976. "The Kingdom of Rwanda". in Forde, Daryll ed. 1976.

Mbiti, J.S. 1969. African Religions and Philosophy. Nairobi: Heinemann Kenya Ltd.

Mourelatos, A.P.D. ed. 1993. The Pre-Socratics. Princeton: Princeton University Press.

Nussbaum, M.C. \& A.O. Rorty eds. 1992. Essays on Aristotle's De Anima. Oxford: Clarendon Press.

Ocholla-ayayo, A.B.C. 1989. "Death and burial: An Anthropological Perspective". Ojwang,J.B. and Mugambi, J.N.K. eds. The S.M. Otieno case: Death and Burial in Modern Kenya. Nairobi: Nairobi University Press, pp.30-51.

O'connor, D.J. ed. 1985. A Critical History of Western Philosophy. New York: The Free Press.

p'Bitek, Okot. 1986. Artist the Ruler: Essays on Art, Culture and Values. Nairobi: East African Educational Publishers Ltd.

Oruka, H.O. ed. 1991. Sage Philosophy: Indigenous Thinkers and Modern Debate on African Philosophy. Nairobi: Acts Press.

Oruka, H.O. \& Masolo, D.A. eds. 1983. Philosophy and Cultures. Nairobi: Bookwise Ltd.

Rheeders, K., 1998. Some Traditional African Beliefs: A Beginners Guide. Abington: Hodder \& Stoghton.

Russell, B., 1961. A History of Western Philosophy. London: George Allen \& Unwin Ltd.

Stanford Encyclopedia of Philosophy.2009. "Ancient Theories of Soul". http://plato.stanford.edu/entries/ancient-soul/

Stumpf, E.S. 1993. Elements of Philosophy: An Introduction, $3^{\text {rd }}$ Ed. New York: McGraw-Hill, Inc.

Tempels, P. 1969. Bantu Philosophy. King, Colin Trans. Paris: Presence Africaine.

Thairu, K., 1975. The African Civilization. Nairobi: Kenya Literature Bureau. 